- RAM, REV. ADM. MACKENZIE, 17(3) • SÃO PAULO, SP • MAIO/JUN. 2016 • ISSN 1518-6776 (impresso) • ISSN 1678-6971 (on-line) • http://dx.doi.org/10.1590/1678-69712016/administracao.v17n3p105-131. Submissão: 10 ago. 2015. Aceitação: 14 dez. 2015. Sistema de avaliação: às cegas dupla (double blind review). UNIVERSIDADE PRESBITERIANA MACKENZIE. Silvio Popadiuk (Ed.), Paulo Sergio Ceretta (Ed. Seção), p. 105-131

\title{
. \\ CAPITAL STRUCTURE OF BRAZIL, RUSSIA, INDIA AND CHINA BY ECONOMIC CRISIS
}

EDILSON DOS SANTOS SILVA

Doctor in Business Administration from the Graduate Program in Business Administration at the Universidade Federal de Pernambuco (UFPE).

Professor I for the Department of Business Administration at the Centro Universitário Tiradentes (Unit). Avenida Comendador Gustavo Paiva, 5017, Cruz das Almas, Maceió - AL - Brasil - CEP 57038-000

E-mail: santosedilson@hotmail.com

\section{JOSETE FLORENCIO DOS SANTOS}

Doctor in Business Administration from the Institute of Graduation and Research in Business Administration at the Universidade Federal do Rio de Janeiro (Coppead-UFRJ).

Associate Professor 2 for the Graduate Program in Business Administration at the Universidade Federal de Pernambuco (Propag-UFPE).

Av. dos Funcionários, s.n., $7^{\circ}$ andar, sala D-18, Cidade Universitária, Recife - PE - Brasil - CEP 50740-580

E-mail: jfs@ufpe.br

\section{FERNANDA FINOTTI CORDEIRO PEROBELLI}

Doctor in Business Administration from the College of Economics, Management and Accounting at the Universidade de São Paulo (FEA-USP). Associate Professor IV for the College of Economics at the Universidade Federal de Juiz de Fora (UFJF). Campus Universitário, Martelos, Juiz de Fora - MG - Brasil - CEP 36900-000

E-mail: fernandafinotti.perobelli@ufif.edu.br

\section{WILSON TOSHIRO MAKAMURA}

Doctor in Business Administration from the College of Economics, Management and Accounting at the Universidade de São Paulo (FEA-USP). Assistant Professor III for the Graduate Program in Business Administration at the Universidade Presbiteriana Mackenzie (UPM). Rua da Consolação, 896, Prédio 45, Consolação, São Paulo - SP - CEP $01302-907$ E-mail:wtnakamura@uol.com.br

Este artigo pode ser copiado, distribuído, exibido, transmitido ou adaptado desde que citados, de forma clara e explícita, o nome da revista, a edição, o ano e as páginas nas quais o artigo foi publicado originalmente, mas sem sugerir que a RAM endosse a reutilização do artigo. Esse termo de licenciamento deve ser explicitado para os casos de reutilização ou distribuição para terceiros. Não é permitido o uso para fins comerciais. 


\section{ABSTRACT}

Purpose: Verify the effects of the subprime mortgage crisis on firms with different debt levels.

Originality/gap/relevance/implications: The study contributes to the literature by examining the financial capital structure of emerging market companies in a context of crisis, in addition to using a robust econometric tool - the quantile regression.

Key methodological aspects: In this work, the quantile regression was used as an analysis tool, and this technique allowed to observe the impacts of the crisis not only in the average level of indebtedness of companies, but also in its extreme values. Therefore, this work is characterized as descriptive, and the analyzed relations are quantitative. Firms were analyzed in Brazil, Russia, India and China.

Summary of key results: The results indicate financing strategies, according to the theories of Pecking Order and Trade-off as regards to the level of debt.

Key considerations/conclusions: The survey concluded that firms have different financing strategies even in the same country. Thus, the financial performance of firms would be influenced by economic conditions in the country, as well as the existing debt level in each company.

\section{KEYWORDS}

Pecking order. Trade-off. Capital structure. Emerging countries. Economic crisis.

\section{INTRODUCTION}

For nearly half a century, a broad debate on the composition of the capital structure has taken place in academia, focusing on costs and benefits of debt (tradeoff theories), asymmetric information and hierarchy of funding (Pecking Order Theory), agency costs and influence of market conditions (market timing theory). 
The various theoretical perspectives on the topic have different assumptions. The trade-off theory assumes that firms seek a balance between the tax benefits of debt and the expected bankruptcy costs (Frank \& Goyal, 2007a; Myers, I977). The agency theory also considers the costs and benefits of debt generated by the separation between capital and control (Brounen, Jong, \& Koedijk, 2005; Jensen, \& Meckling, I976). According to the pecking order theory, the costs (direct and indirect) of issuing new shares make the company more willing to finance using retained earnings (the source of lower information asymmetry), followed by private and public debt and leaving shares as a last resort (Mojtahedzadeh, 20Ir; Shyam, Sunder, \& Myers, I999). Finally, according to the market timing theory, firms capital structure reflects the attempts of the managers to issue shares or debt when the market prices are attractive (Frank \& Goyal, 2007b; Strebulaev, 2007; Myers, 2003).

This paper have studied the major theories of capital structure - trade-off and pecking order - in the context of Bric's (Brazil, Russian, India and China) firms during the 2007 financial crisis. Discussions about which of those theories best explains the behavior of firms remains until nowadays and are present in the work of Mojtahedzadeh (2OII), Schaeffler (2OI2), Koksal and Orman (20I4), among others.

Over the years, several empirical studies have been conducted in the light of these theories, trying to identify what makes firms define their capital structure, especially in the most developed markets. Strebulaev (2007) built a model to capture the behavior of firms in times of financial difficulty. The author found that the decisions on capital structure are dynamics. In addition, firms of the same sector can exhibit different financial behaviors because such behaviors are due to specific shocks and financial past decisions. About this fact, Lemmon, Roberts and Zender (2008) observed that the debt converges over time; however, companies with high (low) debt levels tend to remain relatively high (low) for about 20 years. The authors emphasize the importance of fixed factors (not observable) over the classical determinants of capital structure.

Jong, Kabir and Nguyen (2008) highlight the importance of developing the capital markets, which facilitates the issuance and trading of securities (debts or stocks), providing higher levels of leverage and funding. In the most recent work on the subject, there seems to be an understanding that firms financing decisions are determined not only by factors specific to each firm, but also by external factors to them and to which each firm has a sensitivity. Fan, Titman and Twite (2OI2) state that the country where the company resides is an important determinant of how the company is financed, being fundamental institutional factors very important to corporate financing decisions. 
Although some studies have emphasized the importance of the institutional environment, a large portion of studies to date only concerns to firm factors capable of influencing their capital structure. Factors that emerge in almost all studies, in several countries, are related to company size, growth opportunities, asset tangibility, profitability and risks involved.

Although financing decisions may be affected by the same variables at firm level, there are differences in how debt levels are affected by macroeconomic factors in each country, as the GDP growth rate, inflation rate, etc. Thus, it is important to consider macroeconomic and institutional factors that can influence the capital structure of companies, especially in countries with unstable environment, such as those in Latin America, as noted by Favato and Rogers (2008) and Bastos, Nakamura and Basso (2009).

Thus, it is understood that there is still room to evaluate financing decisions in financial stress situations (economic crisis) and in emerging countries, such as those that make up the Bric's block (Brazil, Russia, India and China), as they play a significant role in the world economy.

Study emerging countries is important in order to expand the current knowledge on corporate financing policies, since much of what is already done in this area was generated and tested in developed countries. Bekaert and Harvey (2002) suggest that conducting studies in order to verify relationships among markets in times of crisis, as well as in emerging markets, is important to the empirical test and proof of financial theories.

As for financial stress situations, we want to highlight the credit crisis in the United States in 2007 (subprime mortgage crisis), given its magnitude, which slowed global production, wiped international liquidity and caused impacts on investment and financing decisions of firms. According to International Monetary Fund (2OI2), the recovery of production in the affected countries has been different between developed and emerging markets.

The effect of the crisis on the firms capital structure has been exploited by some studies, which have observed features as the financial constraints of enterprises, investment decisions and the economic environment. Desai, Foley and Forbes (2004) found evidence of financial constraints effects on business growth during periods of crisis in emerging markets. For the authors, companies tend to increase their debt levels, indicating a financial weakness, after periods of recession.

Campello, Graham and Harvey (2009) analyzed the investment decisions of financial managers from different countries, and found that companies that face financial difficulties usually plan to cut investment (in technology, marketing and employment). In addition, $90 \%$ of companies with financial constraints 
limit themselves to seek attractive projects, and more than half of these companies are forced to cancel important investments. Lima, Assaf, Neto, Perera and Silva (20II) found evidence of the relationship between macroeconomic indicators (exchange rate, interest rate and inflation) and the capital structure of Brazilian companies along the subprime mortgage crisis. The authors concluded that there is a correlation between macroeconomic factors and capital structure, i.e., in periods of inflation under control, companies increase their debt levels.

In order to justify this study, we would like to state that economic crisis periods enable the expansion of knowledge, to the extent that companies are affected in different ways by such events, so the financial policies of corporations may be influenced to a greater or lesser degree according to the effect of macroeconomic events on each structure. In addition, we can observe companies with different levels of debt in a period of crisis.

Recognizing the economic and institutional differences among emerging countries (represented by countries that make up the Bric's block) and that these countries can act in different ways in times of economic growth and recession, the question is: what are the effects of the crisis on debt levels of companies of Brazil, Russia, India and China? It is worth noting that the importance of the Bric's is not homogeneous among them: Brazil and Russia stand out as major suppliers of primary products, and India and China are focused on production technologies (Almeida, 20I0). As these countries have different realities, mainly the economic situation under the global economic crisis, observing them will assess how companies in different environments behave in times of instability.

To contribute to the literature of capital structure beyond the context of economic crisis and emerging countries, this work makes use of quantile regression as an analytical tool, since the effects of the subprime mortgage crisis may have varied according to levels of indebtedness of companies and not just caused impacts on the average level of debt. So, this technique will help us observe the impact of the crisis not only on the average level of indebtedness of companies, but also on its extreme values.

According to Cameron and Trivedi (2010), the quantile regression is more sensitive to the presence of outliers and can be more robust when the dependent variable has a non-homogeneous distribution; thus, it will be appropriate for analyzing the capital structure, as will be analyzed companies with different debt levels.

The work is structured as follows: the next section presents the methodological procedures. Section 3 presents the research results, and the last section presents the final considerations. 


\section{METHODOLOGICAL PROCEDURES}

This study is characterized as descriptive and quantitative. For Cervo, Bervian and DaSilva (2007), descriptive research notes, records, analyzes and correlates events and phenomena without manipulating them. In other words, this type of research describes characteristics, existing properties or relationships in the community, group or researched reality.

\subsection{SAMPLE}

The survey sample was made up of all publicly traded companies listed on stock exchanges in Brazil, Russia, India and China. The exclusion of private companies is justified by the unavailability of data. Information was collected from annual balance sheets and consolidated statements of firms. Accounting/financial values were obtained in US Dollars, in thousands, in order to allow comparisons. The sample was obtained from the international Global Compustat database. Financial companies, companies that have not presented data in all years and companies exhibiting negative equity have been eliminated from the final sample.

Finally, the timeline refers to the time required for checking the main objective of this work, that is, if the main theories of capital structure can elucidate the capital structures of companies in emerging countries through the crisis scenario started in 2007. According to Arellano and Bond (I99I) at least five years of data are needed for a robust analysis; thus, in this study, the selected period covers the years from 2002 to 20II. Considering the beginning of the crisis in 2007 , the sample of this study presents five years of observations before the crisis and four years after the crisis (provided by data availability). Thus, it seeks to investigate a period beyond the analyzed one by Öztekin (20II) and Ivashkovskaya and Solntseva (2008), among others, on cross-country studies.

Macroeconomic data were obtained from the International Finance Corporation website (World Bank). Among the macroeconomic data, GDP growth rate (annual, \%) and inflation rate (annual, \%) were collected. Descriptive statistics and graphics of the main variables were obtained through Stata I2 software.

\subsection{METHOD OF ANALYSIS OF DATA}

To achieve the goal of this study, the quantile regression was used, similarly to the works of Oliveira, Tabak, Resende and Cajueiro (20I2), Wellalage and Locke (20I2) and Fattouh, Scaramozzino and Harris (2008). Data were examined by means of a cross-section pooled analysis. 


\subsubsection{Quantile regression}

The quantile regression is a useful tool to study heterogeneous data, such as the different levels of debt shown by companies. In addition, quantile regression coefficients may be consistent under a weak stochastic approach, when compared with the results of an ordinary least squares regression (Cameron \& Trivedi, 2005).

In this study, the regressions were performed for the quantiles 0.05; 0.25; $0.50 ; 0.75$ and 0.95 , according to studies of Wellalage and Locke (2012), Oliveira et al. (2012), among others. The regressions quality was measured using standard errors obtained via bootstrap. According to Koenker (2005), bootstrap has been used in quantile regression applications as it is effective for independent variables not identically distributed, as it obtains a good performance in small samples and as it displays a covariance matrix adaptable to various forms of heterogeneity.

\subsubsection{Specification of the level of debt analysis model}

The model used was derived from Öztekin studies (20II), Antoniou, Guney and Paudyal (2008), Rajan and Zingales (1995), among others. The debt analyzed was long-term book value (END). Relations between the determinants of capital structure and debt levels are represented in the following model:

$\mathrm{END}_{i t}=\beta_{\mathrm{o}}+\beta_{\mathrm{I}} T A N G_{i t-\mathrm{I}}+\beta_{2} L U C R A_{i t-\mathrm{I}}+\beta_{3} O P O R T_{i t-1}+\beta_{4}$ TAM $_{i t-\mathrm{I}}+\beta_{5} R I S C O_{i t-\mathrm{I}}$ $+\beta_{6} P_{I B_{t-I}}+\beta_{7} I N F_{t-I}+\beta_{8} C R I S E_{i t}+\mu_{i t}$

Where:

$\mathrm{END}_{i t}$ - Book value of company long term debt in each period $t$

$T A N G_{i t-\mathrm{I}}$ - Tangibility of company assets i (lagged one period)

LUCRAT $T_{i t-\mathrm{I}}$ - Profitability of company i (lagged one period) period)

OPORT ${ }_{i t-\mathrm{I}}{ }_{t-\mathrm{I}}-$ Proxy for growth opportunities of the company i (lagged one

$T A M_{i t-\mathrm{I}}-$ Size of company i (lagged one period)

RISCO $_{i t-\mathrm{I}}$ - Business risk of company i (lagged one period)

$T_{P I B_{t-\mathrm{I}}}$ GDP growth rate (lagged one period)

$T_{I N F_{t-1}}$ - Inflation rate (lagged one period)

$C R I S E_{i t}$ - Dummy variable that captures the effects of the crisis on the company $i$ at time $t$

To set the model used in this study, empirical cross-countries studies on capital structure were analyzed and it was decided to use the variables that are 
considered the classical ones according to capital structure literature (tangibility, profitability, growth opportunities, size, business risk). It was selected those that had influence in determining the capital structure of the independent companies in the country in question (despite economic and institutional differences that may enhance the effects of the determinants of capital structure), as found by Rajan and Zingales (I995), Booth, Aivazian, Demirguc-Kunt and Maksimovic (200I), Öztekin and Flannery (20II), among others.

The literature suggests that tangible assets are important since they can be provided as collaterals to third parties; thus, a positive relationship between debt and tangibility is suggested under the theories of trade-off and pecking order. It is also expected that companies with large amounts of fixed assets issue more long-term debt than companies with few fixed assets, as those companies are generally more diversified and have more stable cash flows (Jong et al., 2008).

Empirical evidence for the profitability points different interpretations as theoretical predictions. The negative relationship between profitability and debt is interpreted as consistent with the pecking order theory and inconsistent with the trade-off theory. According to the static trade-off theory, the most profitable companies should be more indebted because bankruptcy costs would be lower and the tax benefits of debt would be higher (Koksal \& Orman, 20I4). Then, the pecking order theory argues that profitable firms prefer internal financing in relation to external funding (debt and new equity) to finance new investments; consequently, more profitable companies may have lower debt levels (Frank \& Goyal, 2007a).

Another factor related to the levels of indebtedness is the market-to-book value ratio, a proxy for growth opportunities of the companies or their performance. The market-to-book ratio has different interpretations for theories of capital structure. According to Öztekin (20II), a negative signal to the marketto-book ratio supports both theories of trade-off and market timing. However, this variable can also be interpreted by the pecking order theory, in which case it assumes positive values, as more growth expectations require more borrowing (Bastos, Nakamura, \& Basso, 2009).

The size of the company also has influence on the levels of indebtedness of companies. Theory of trade-off usually interprets this variable as large companies will be more indebted, since they are more diversified and have lower default risk. Under the pecking order theory, it is normally expected an inverse relationship between leverage and firm size. The argument is that large companies face little adverse selection and can issue more easily shares compared to small businesses, where the adverse selection problems are severe (Frank \& Goyal, 2007a). 
As regards to the risk attribute, firms with more volatile cash flows are more suitable to present higher financial distress costs (bankruptcy costs and debt's agency costs) and should use less debt (Frank \& Goyal, 2007a; Antoniou, Guney, \& Paudyal, 2008). The trade-off theory predicts that companies reduce the risk to increase borrowing capacity. The risk is harmful to shareholders and potential investors, so riskier companies should use less debt. Companies with more volatile cash flows, however, may require external funds to cover its deficit.

In addition to the classic determinants of capital structure, we have used in this study macroeconomic variables (growth of gross domestic product and inflation rate) that present themselves as important factors in the financial behavior of companies. According to empirical literature, in countries with a better legal environment and more stable economic conditions, companies are more likely to have lower debt ratios (Jong et al., 2008). In this context, the pecking order is maintained, and leverage should decline during expansions, since the internal funds availability increases.

Frank and Goyal (2009b) state that, in recent years, inflation rates have not been highlighted in the literature on capital structure; however, the effects are still presented in data. According to the authors, the trade-off theory predicts a positive relationship between leverage and the expectation of inflation. The positive relationship can also be observed in the market timing theory; therefore, managers would issue debt when inflation expectations are relatively high in relation to current interest rates.

To verify the explanatory power of theories of capital structure, in this study, comparisons were made between the results and predictions of the determinants according to the theories of pecking order and trade-off, i.e., the observed results (signs of found coefficients) were confronted with the signs of the determinants of capital structure as stated by literature.

To analyze the data, it was made a pooled analysis. In a pooled analysis, or combined data, elements of time series and cross-section are present. Alexander, Harding and Lamarche (20II) emphasize the robustness of quantile regression also in the time-series-cross-section analysis, noting that the method allows to obtain insights into the effects of covariates on the variable of interest by allowing a reading of heterogeneous effects by data arrangement, since in the average regression models, usually, the heterogeneity is not considered, although being found in the pooled data.

Regarding the endogeneity, it is important to note that, in corporate finance, this problem may be caused by the omission of important variables, by measurement error of covariates and/or by simultaneity, as Barros, Castro, Silveira and Bergmann (2010) pointed out. To minimize those effects, in this study, the debt was used a period ahead $(t+I)$ as the dependent variable. 
Chernozhukov, Hansen and Jansson (2006) state that, even in small samples, the quantile regression results can be relied on models that include endogenous variables. However, the approach developed by them to solve the problem of endogeneity may be difficult to implement computationally because it requires the reversal of an objective function that can be very difficult if the number of parameters is large.

\subsection{OPERATIONALIZATION OF VARIABLES}

The dependent variable used is book value of long-term debt. The debt was analyzed according to the following definitions:

\section{CHART I}

\section{DEPENDENT VARIABLE}

\begin{tabular}{ll}
\hline VARIABLE & DESCRIPTION \\
\hline END: long-term debt at book value & $=$ Long-term debt / total assets \\
\hline
\end{tabular}

Source: Elaborated by the authors.

By choosing the dependent variable to be measured by book value, we are releasing the measure of financial markets fluctuations and making the study affordable, since the accounting information act as a guide for the financial policy of companies (Frank \& Goyal, 2007a).

The explanatory variables, i.e., the determinants of used capital structure are as follows:

\section{CharT 2}

INDEPENDENT VARIABLES

\begin{tabular}{ll}
\hline VARIABLES & DESCRIPTIONS \\
\hline TANG: tangibility & $=$ Fixed assets / total assets \\
\hline LUCRAT: profitability & $=$ Operating Income / Total Assets \\
\hline OPORT: growth opportunity & $=$ (Total assets - Equity + Total Market Value of Shares) \\
& $/$ Total Assets \\
\hline TAM: company size & $=\ln$ (total assets) \\
\hline
\end{tabular}

(continue) 


\section{CHART 2 (CONCLUSION)}

\section{INDEPENDENT VARIABLES}

\begin{tabular}{ll}
\hline VARIABLES & DESCRIPTIONS \\
\hline RISCO: business risk & $=$ Standard deviation Operating Income / Total Assets \\
CRISE & $=$ Dummy variable that captures the effects of the crisis \\
\hline TPIB & $=$ Annual rate of GDP growth \\
\hline TINF & $=$ Annual inflation rate \\
\hline
\end{tabular}

Source: Elaborated by the authors.

\section{RESULTS}

This chapter presents the empirical results obtained in the research. Initially, macroeconomic factors and corporate indebtedness summary statistics will be presented; then, the analysis of the capital structure of companies in emerging countries (Bric's) will take place.

Macroeconomic conditions can influence behavior in the financial activities of companies, so it is interesting to note the potential changes brought in them over time. Emerging economies with high economic potential (Bric's) exhibit an important role in the world economy; however, these economies have peculiarities that differentiate them from each other, as the economic and institutional development.

The data presented in graphs I and 2 shows the differences between these countries. Thus, it can be observed that, despite the fluctuations in GDP growth rate, there was a trend of economic growth in emerging countries. However, by 2007 , the effects of the subprime mortgage crisis begin to appear, culminating in a recession; and, as of 2010 , the economy of these countries begin to balance. 


\section{GRAPH I}

\section{GDP GROWTH RATE OF EMERGING COUNTRIES}

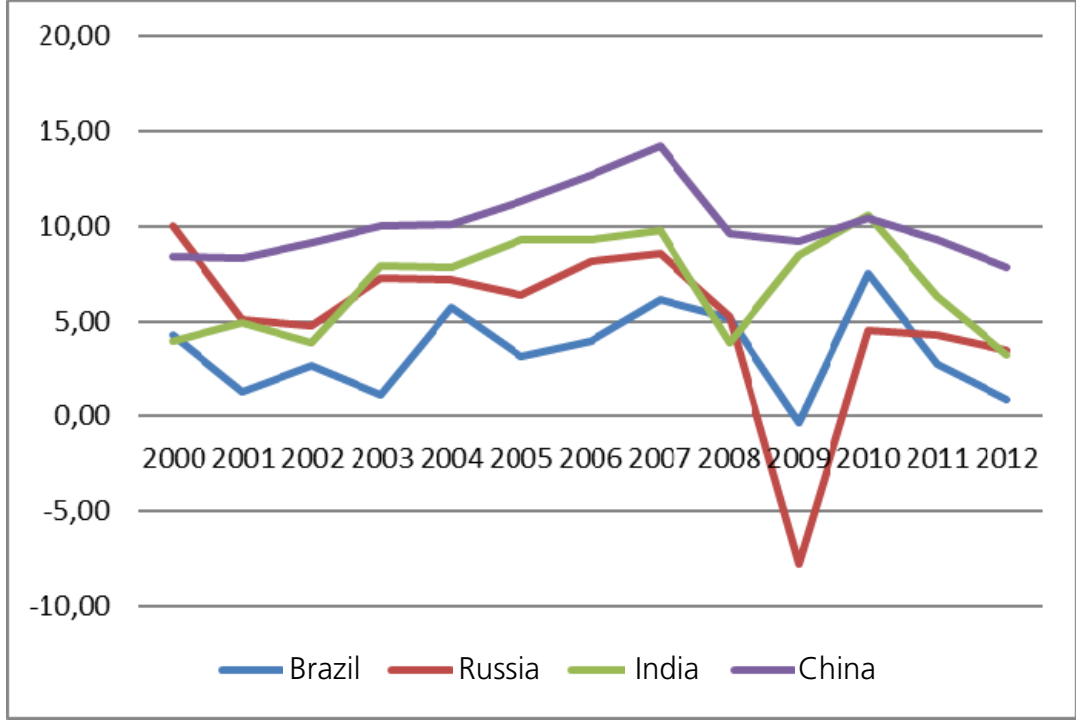

Source: Elaborated by the authors.

\section{GRAPH 2}

INFLATION RATE IN EMERGING COUNTRIES

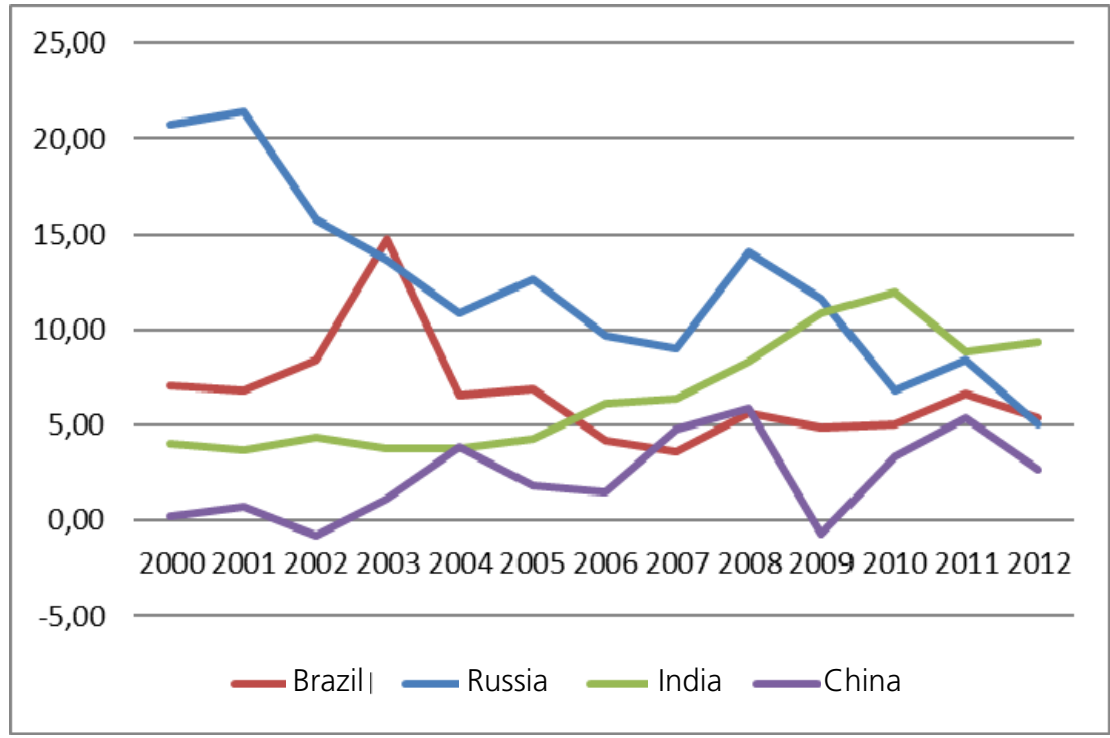

Source: Elaborated by the authors. 
Regarding the inflation rate in Brazil, inflation control policies appear to have been driven to try to preserve the local economy from the effects of the crisis. This reflection is present in changing the inflation index: until mid-2007 it showed a downward trend and then presented slightly higher levels. This fact points out to the need to strengthen the economy against external effects through a quantitative easing in macroeconomics.

The participation of India in the world economy has grown in recent years, due to changes provided by economic, financial and banking reforms. These events provided a closer economic growth to China's economy (Reddy, 20I5).

The effects of the subprime mortgage crisis can also be seen through the debt levels of the companies before and after the crisis, as shown in Graph 3. In such graph, it is possible to see that the long-term debt (measured at book value) increased by approximately 50\% in Brazilian, Russian and Chinese companies. Only Indian companies showed a reduction of long-term debt levels. According to IMF (2010), fiscal and monetary policies have been important factors in the recovery of the global economy. These actions allowed the advanced and emerging economies contribute to the recovery of global economic activity. These indicators signal effect on financing decisions of firms in Brazil, Russia, India and China, according to the economic and institutional reality of each country.

\section{GRAPH 3}

\section{LONG-TERM DEBT THE AVERAGE BOOK VALUE}

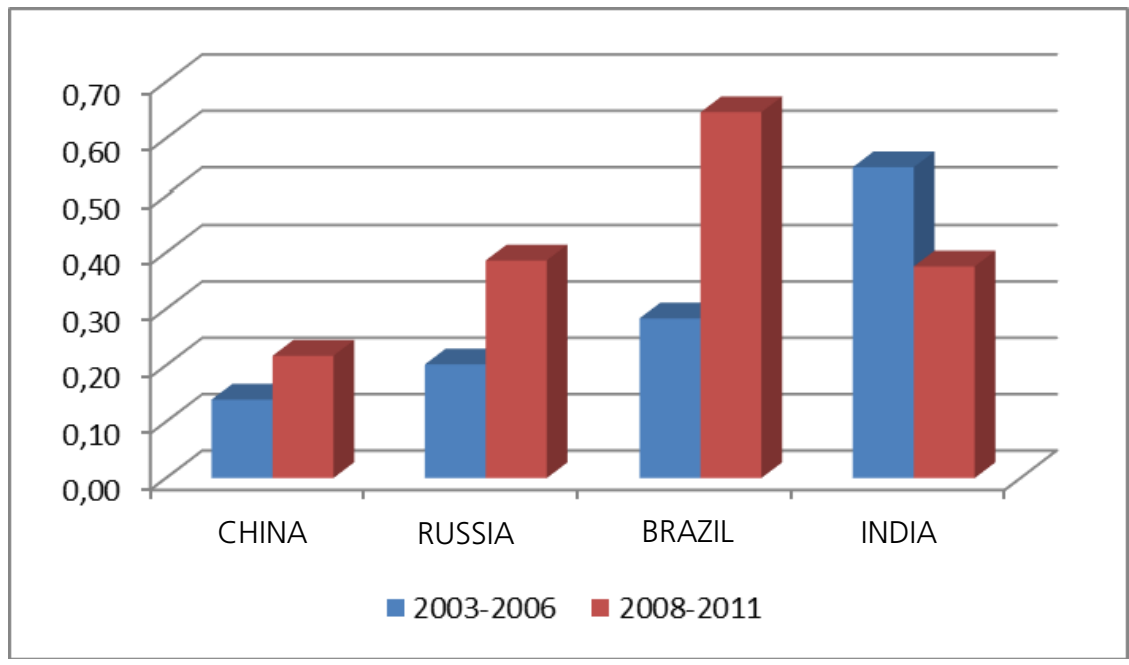

Source: Elaborated by the authors. 
The impact of the global crisis to Brazil, Russia, India and China reveals its strengths and weaknesses in a different context to the period before 2008. China appears to have resisted the slumping in early 2009 (a reduction of $40 \%$ in exports global). In 20I0, China begins to signal a growth rate similar to the previous decade. The Russian economy has the greatest difficulties among Bric's countries, for presenting a dependence on primary commodity exports, apart from the difficulty to compete internationally with innovative manufacturing. India, like China, resisted well to the effects of the crisis. Brazil kept its economic growth, provided by the minimum international exposure and trade relations with China (Almeida, 20I0).

To analyze the effects of the subprime mortgage crisis on the indebtedness of enterprises (considering distinct levels of debt), a quantile analysis pooled cross-section was performed in order to confirm the possible effects of macroeconomic environment on corporate financing strategies.

In this study, variations were found in the effects of the determinants of capital structure, according to the quantile, similar to the works of Fattouh et al. (2003), Hallock, Madalozzo and Reck (2008) and Wellalage and Locke (2012). The different effects of the classical determinants of the capital structure through the quantile enrich the financial literature, since companies with different debt levels may have different financial behaviors.

Results for Brazilian companies can be seen in Table I. The results show the tangible assets as a determinant of borrowing by companies located in quantile 0.25 . However, there is a negative relationship between tangibility and longterm debt. In other words, for least indebted companies, in general, other factors seem to be more important in minimizing the risks for lenders. This may signal that it is interesting to know the characteristics of industry sectors to understand the behavior of these companies.

TABLE I

QUANTILE REGRESSION RESULTS POOLED

CROSS-SECTION FOR BRAZILIAN COMPANIES

\begin{tabular}{lcccccc}
\hline & \multicolumn{5}{c}{ END } \\
\hline VARIABLES & & RQ 0.05 & RQ 0.25 & RQ 0.50 & RQ 0.75 & RQ 0.95 \\
\hline \multirow{2}{*}{ TANG } & $\beta$ & -0.001093 & $-0.013698^{* *}$ & 0.004765 & 0.018079 & 0.055549 \\
\cline { 2 - 7 } & e.p. & 0.001819 & 0.006340 & 0.022935 & 0.033129 & 0.220692 \\
\multirow{2}{*}{ LUCRAT } & $\beta$ & -0.009222 & -0.054118 & -0.215111 & -0.534575 & -2.692699 \\
\cline { 2 - 7 } & e.p. & 0.018121 & 0.077992 & 0.444366 & 1.952134 & 3.672710 \\
\hline
\end{tabular}

(continue) 
TABLE I (CONCLUSION)

QUANTILE REGRESSION RESULTS POOLED

CROSS-SECTION FOR BRAZILIAN COMPANIES

\begin{tabular}{|c|c|c|c|c|c|c|}
\hline \multirow{2}{*}{ VARIABLES } & & \multicolumn{5}{|c|}{ END } \\
\hline & & RQ 0.05 & RQ 0.25 & RQ 0.50 & RQ 0.75 & RQ 0.95 \\
\hline \multirow{2}{*}{ OPORT } & $\beta$ & -0.000068 & -0.000147 & -0.000429 & -0.000992 & -0.004798 \\
\hline & e.p. & 0.000461 & 0.002512 & 0.008194 & 0.010684 & 0.039079 \\
\hline \multirow{2}{*}{ TAM } & $\beta$ & -0.000855 & -0.003755 & -0.004186 & -0.006728 & 0.027656 \\
\hline & e.p. & 0.001003 & 0.004147 & 0.004705 & 0.015518 & 0.082808 \\
\hline \multirow{2}{*}{ RISK } & $\beta$ & $-6.75 e-06$ & -0.000123 & $-2.94 \mathrm{e}-06$ & 0.000131 & -0.002596 \\
\hline & e.p. & 0.000049 & 0.000299 & 0.000730 & 0.004557 & 0.007738 \\
\hline \multirow{2}{*}{ TPIB } & $\beta$ & 0.000437 & 0.000885 & 0.000211 & 0.001348 & 0.008377 \\
\hline & e.p. & 0.000329 & 0.000915 & 0.001892 & 0.007162 & 0.033990 \\
\hline \multirow{2}{*}{ TINF } & $\beta$ & 0.000236 & 0.001357 & 0.001544 & 0.001358 & 0.002176 \\
\hline & e.p. & 0.000249 & 0.000946 & 0.001600 & 0.005228 & 0.027388 \\
\hline \multirow{2}{*}{ CRISIS } & $\beta$ & -0.000455 & 0.010564 & 0.016175 & 0.024895 & 0.206564 * \\
\hline & e.p. & 0.002586 & 0.009923 & 0.014337 & 0.047113 & 0.123595 \\
\hline \multirow{2}{*}{ Const. } & $\beta$ & $0.006074 * * *$ & $0.063633^{* * *}$ & $0.165728 * * *$ & $0.278732 * * *$ & 0.683259 \\
\hline & e.p. & 0.001212 & 0.003233 & 0.008122 & 0.053001 & 0.480426 \\
\hline \multicolumn{2}{|c|}{ Pseudo R2 } & 0.0028 & 0.0040 & 0.0067 & 0.0122 & 0.0482 \\
\hline \multicolumn{2}{|c|}{ Observations } & & & 1954 & & \\
\hline
\end{tabular}

The variables studied were the long-term debt lagged the book value (END), the tangibility (TANG), profitability (LUCRAT), the opportunity for growth (OPORT), firm size (TAM); business risk (RISK), the growth rate of GDP (TPIB), inflation rate (TINF), and a dummy variable that captures the effects of the crisis (CRISIS). The definitions of variables of companies can be seen in section 2.3. This table shows the results for the estimation of regression parameters by the quantile regression method, robust standard error, using 2002-20II data. The coefficients equal test through quantile - (END) $\mathrm{F}=6.0 \mathrm{I}(\mathrm{p}>\mathrm{F}=0.0000)$. *** $\mathrm{P}<0.0 \mathrm{I}$; ** $\mathrm{P}<0.05$; * $\mathrm{P}<0 . \mathrm{I}$.

Source: Elaborated by the authors. 
As for the most indebted companies (quantile o.95), the variable crisis showed a positive relationship, i.e., Brazilian companies with higher debt levels possibly felt more the effects of the economic crisis, since at this time there was much market uncertainty providing a greater fear of creditors towards borro-wers.

For the other quantiles, the quantile regression was not able to find determinants staggered to debt level to these companies.

The evidence for Russian companies (Table 2) suggest the size of the company, gross domestic product and the economic crisis as major factors in determining the capital structure of Russian companies, for quantile $0.25 ; 0.50$ and 0.75 . For this group of companies, size variable showed a negative relationship with the long-term debt (this negative relationship suggests a behavior according to the pecking order theory). Note that the "size of company" factor increases its importance as debt levels increases.

\section{TABLE 2}

QUANTILE REGRESSION RESULTS POOLED

CROSS-SECTION FOR RUSSIAN COMPANIES

\begin{tabular}{lcccccc}
\hline & \multicolumn{5}{c}{ END } \\
\hline VARIABLES & & RQ 0.05 & RQ 0.25 & RQ 0.50 & RQ 0.75 & RQ 0.95 \\
\hline \multirow{2}{*}{ TANG } & $\beta$ & -0.000028 & -0.004037 & -0.003943 & 0.000257 & 0.010893 \\
\cline { 2 - 7 } & e.p. & 0.001424 & 0.004365 & 0.007517 & 0.021752 & 0.042162 \\
\hline \multirow{2}{*}{ LUCRAT } & $\beta$ & 0.006174 & 0.011098 & -0.021372 & -0.077102 & 0.158171 \\
\cline { 2 - 7 } & e.p. & 0.007201 & 0.028332 & 0.041167 & 0.078591 & 0.132544 \\
\hline \multirow{2}{*}{ OPORT } & $\beta$ & -0.000109 & -0.001858 & -0.000212 & -0.000099 & -0.005493 \\
\cline { 2 - 7 } & e.p. & 0.001156 & 0.002128 & 0.001598 & 0.003288 & 0.010626 \\
\hline \multirow{2}{*}{ TAM } & $\beta$ & -0.000344 & $-0.004229 * * *$ & $-0.008289 * * *$ & $-0.010933 * * *$ & -0.010948 \\
\cline { 2 - 7 } & e.p. & 0.000408 & 0.001075 & 0.002641 & 0.004011 & 0.018989 \\
\hline \multirow{2}{*}{ RISK } & $\beta$ & $0.000266 * *$ & 0.000555 & -0.000199 & -0.001671 & 0.003430 \\
\cline { 2 - 7 } & e.p. & 0.000126 & 0.001442 & 0.001829 & 0.003801 & 0.004685 \\
\hline \multirow{2}{*}{ TPIB } & $\beta$ & 0.000156 & $0.003655 * * *$ & $0.003249 * * *$ & $0.003286 * * *$ & 0.0002308 \\
\hline & e.p. & 0.000351 & 0.001105 & 0.000629 & 0.001217 & 0.002548 \\
\hline
\end{tabular}


TABle 2 (CONClusion)

QUANTILE REGRESSION RESULTS POOLED

CROSS-SECTION FOR RUSSIAN COMPANIES

\begin{tabular}{lrrrrrr}
\hline & \multicolumn{5}{c}{ END } \\
\hline VARIABLES & & RQ 0.05 & RQ 0.25 & RQ 0.50 & RQ 0.75 & RQ 0.95 \\
\hline \multirow{2}{*}{ TINF } & $\beta$ & -0.000206 & $-0.002501 *$ & -0.001364 & -0.003065 & -0.007520 \\
\cline { 2 - 7 } & e.p. & 0.000455 & 0.001489 & 0.001435 & 0.003518 & 0.004788 \\
\hline \multirow{2}{*}{ CRISIS } & $\beta$ & 0.000758 & $0.031878 * * *$ & $0.041739 * *$ & 0.033551 & -0.034184 \\
\cline { 2 - 7 } & e.p. & 0.004137 & 0.012245 & 0.016562 & 0.035761 & 0.044840 \\
\hline \multirow{2}{*}{ Const. } & $\beta$ & 0.002160 & $0.038396 * *$ & $0.106440 * * *$ & $0.216866 * * *$ & $0.409324 * * *$ \\
\cline { 2 - 7 } & e.p. & 0.001391 & 0.004300 & 0.008204 & 0.012150 & 0.028768 \\
\hline Pseudo R2 & 0.0013 & 0.0210 & 0.0195 & 0.0184 & 0.0219 \\
\hline Observations & 990 & & & & \\
\hline
\end{tabular}

The variables studied were the long-term debt lagged the book value (END), the tangibility (TANG), profitability (LUCRAT), the opportunity for growth (OPORT), firm size (TAM); business risk (RISK), the growth rate of GDP (TPIB), inflation rate (TINF), and a dummy variable that captures the effects of the crisis (CRISIS). The definitions of variables of companies can be seen in section 2.3. This table shows the results for the estimation of regression parameters by the quantile regression method, robust standard error, using 2002-20II data. The coefficients equal test through quantile - (END) F $=14.99$ ( $\mathrm{p}>\mathrm{F}=0.0000$ ). *** $\mathrm{P}<0.0 \mathrm{I} ; * * \mathrm{P}<0.05 ; * \mathrm{P}<0 . \mathrm{I}$.

Source: Elaborated by the authors.

It is important to remember that the mortgage crisis may have favorably influenced the debt of Russian companies via lower interest rates (Graph 2), since there is a positive and statistically significant relationship for Russian companies (quantile 0.25 and 0.50 ). The variable "rate of growth of GDP" showed a positive relationship, indicating that companies need more financial resources into recession scenarios, against the pecking order. This result can be consequence of inflation control policies in order to resume economic growth. For Jong et al. (2008), these results indicate that in countries with relatively high rates of economic growth, companies exhibit higher levels of debt to finance its investments.

For companies less indebted in the long run ( 0.05 quantile), the business risk showed a positive and statistically significant relationship, contrary to the 
predictions of theories of pecking order and trade-off. Antoniou et al. (2008) argue that firms with high volatility in profits may be at risk of seeing their liquidity decline at lower levels than necessary to meet its debt commitments. This may result in the need to raise funds at higher costs or be facing the risk of bankruptcy. Therefore, companies with highly volatile earnings should have less debt.

Table 3 shows the results for Indian companies. In this country, unlike formers analyzed, the long-term debt levels decreased after the period of the subprime mortgage crisis (Graph 3). To Amutha (20I4), this fact can be explained also by government policy control risk, which prevent the institutions to take excessive risks and financial markets become very volatile, in addition to the growth in domestic demand and little dependence of external resources.

\section{TABLE 3}

QUANTILE REGRESSION RESULTS POOLED

CROSS-SECTION FOR INDIAN COMPANIES

\begin{tabular}{|c|c|c|c|c|c|c|}
\hline \multicolumn{7}{|c|}{ END } \\
\hline VARIABLES & & RQ 0.05 & RQ 0.25 & RQ 0.50 & RQ 0.75 & RQ 0.95 \\
\hline \multirow{2}{*}{ TANG } & $\beta$ & $0.002558 *$ & 0.020664 ** & $0.025959 * * *$ & $0.025799 * *$ & $0.033206^{* *}$ \\
\hline & e.p. & 0.001461 & 0.008320 & 0.008929 & 0.011188 & 0.015298 \\
\hline \multirow{2}{*}{ LUCRAT } & $\beta$ & -0.000886 & -0.014700 & -0.030313 & -0.086490 & -0.042220 \\
\hline & e.p. & 0.001922 & 0.018261 & 0.037078 & 0.062365 & 0.104376 \\
\hline \multirow{2}{*}{ OPORT } & $\beta$ & 0.000035 & -0.002655 & $-0.007543^{* *}$ & $-0.009534^{* *}$ & 0.001980 \\
\hline & e.p. & 0.000142 & 0.002159 & 0.003286 & 0.004751 & 0.007842 \\
\hline \multirow{2}{*}{ TAM } & $\beta$ & -0.000082 & $0.007736 * *$ & $0.013853^{* * *}$ & $0.014063^{* * *}$ & $0.016027 * * *$ \\
\hline & e.p. & 0.000312 & 0.003242 & 0.003618 & 0.003388 & 0.004793 \\
\hline \multirow{2}{*}{ RISK } & $\beta$ & 7.32e-06 & 0.000037 & $0.000103 *$ & $0.000135^{* *}$ & $0.000209 * * *$ \\
\hline & e.p. & $9.85 e-06$ & 0.000028 & 0.000052 & 0.000060 & 0.000037 \\
\hline \multirow{2}{*}{ TPIB } & $\beta$ & 0.000108 & -0.000230 & 0.000216 & -0.000201 & $-0,000832$ \\
\hline & e.p. & 0.000088 & 0.000580 & 0.000689 & 0.000798 & 0,001206 \\
\hline
\end{tabular}




\section{TABle 3 (CONCLUSION)}

QUANTILE REGRESSION RESULTS POOLED CROSS-SECTION FOR INDIAN COMPANIES

\begin{tabular}{lcccccc}
\hline & \multicolumn{5}{c}{ END } \\
\hline VARIABLES & & RQ 0.05 & RQ 0.25 & RQ 0.50 & RQ 0.75 & RQ 0.95 \\
\hline \multirow{2}{*}{ TINF } & $\beta$ & -0.000244 & 0.001330 & $0.004346 * *$ & 0.005242 & $-0,000214$ \\
\cline { 2 - 7 } & e.p. & 0.000221 & 0.001973 & 0.001870 & 0.003428 & 0,004193 \\
\hline \multirow{2}{*}{ CRISIS } & $\beta$ & -0.000326 & -0.007723 & -0.010447 & -0.006707 & 0,005482 \\
\cline { 2 - 7 } & e.p. & 0.000922 & 0.005370 & 0.006981 & 0.010089 & 0,011425 \\
\hline Const. & $\beta$ & $0.003831 * * *$ & $0.064179 * * *$ & $0.168112 * * *$ & $0.308635 * * *$ & $0,520167 * * *$ \\
\cline { 2 - 7 } & e.p. & 0.000287 & 0.002024 & 0.002350 & 0.003041 & 0,005387 \\
\hline Pseudo R2 & & 0.0003 & 0.0022 & 0.0057 & 0.0063 & 0.0061 \\
\hline Observations & & & 15363 & & \\
\hline
\end{tabular}

The variables studied were the long-term debt lagged the book value (END), the tangibility (TANG), profitability (LUCRAT), the opportunity for growth (OPORT), firm size (TAM); business risk (RISK), the growth rate of GDP (TPIB), inflation rate (TINF), and a dummy variable that captures the effects of the crisis (CRISIS). The definitions of variables of companies can be seen in section 2.3. This table shows the results for the estimation of regression parameters by the quantile regression method, robust standard error, using 2002-20II data. The coefficients equal test through quantile - (END) $\mathrm{F}=42.99$ ( $\mathrm{p}>\mathrm{F}=0.0000$ ). *** $\mathrm{P}<0.0 \mathrm{I} ; * * \mathrm{P}<0.05 ; * \mathrm{P}<0 . \mathrm{I}$.

Source: Elaborated by the authors.

The most relevant variables for Indian companies were the "tangibility", "growth opportunities", "size of the company" and "risk". However, tangible assets, company size and business risk appear to be more relevant to the most indebted companies (quantile $0.50,0.75$ and 0.95 ), i.e., during global financial crisis moments, creditors should be more judicious to grant loans, especially for companies with more potential to expropriate wealth; so companies that need more loans and have many investment opportunities should present higher levels of tangible assets, as Rajan and Zingales (I995).

In addition, it is possible that companies have tried to reduce the business risk in order to increase their borrowing capacity, as predicted by trade-off theory (Myers, 2003). 
The inflation rate showed significance only for companies with average indebtedness ( 0.50 quantile), behavior suggested by the trade-off theory. For Frank and Goyal (2007a), this behavior can arise from the need for external resources, and managers would issue debt when expected inflation is high relative to current interest rates (indeed seen in Graph 3).

Relations between the determinants of capital structure and leverage to the Chinese companies can be viewed in the last table. Results demonstrate that the leverage can be determined by the "tangibility" and "size" of the company, though these variables have different impacts on different levels of debt.

Similarly to Indian companies, the importance of tangible assets increases as the debt of Chinese enterprises increases. For Frank and Goyal (2007a), a low expectation of bankruptcy costs and a mild relationship between agency debt problems provide a positive relationship between tangibility and debt.

TABLE 4

QUANTILE REGRESSION RESULTS POOLED

CROSS-SECTION FOR CHINESE COMPANIES

\begin{tabular}{|c|c|c|c|c|c|c|}
\hline & & \multicolumn{5}{|c|}{ END } \\
\hline \multicolumn{2}{|l|}{ VARIABLES } & RQ 0.05 & RQ 0,25 & RQ 0.50 & RQ 0,75 & RQ 0.95 \\
\hline \multirow{2}{*}{ TANG } & $\beta$ & 0.002358 ** & $0,018149 * * *$ & $0.032384^{* * *}$ & $0,036666 * * *$ & 0.031862 ** \\
\hline & e.p. & 0.000931 & 0,003162 & 0.005446 & 0,007651 & 0.013563 \\
\hline \multirow{2}{*}{ LUCRAT } & $\beta$ & 0.001631 & $0,007303^{*}$ & 0.005760 & 0,003302 & -0.000658 \\
\hline & e.p. & 0.002275 & 0,004115 & 0.005870 & 0,007183 & 0.024968 \\
\hline \multirow{2}{*}{ OPORT } & $\beta$ & -0.000123 & $-0,000314$ & -0.000812 & $-0,001379$ & -0.004348 \\
\hline & e.p. & 0.000090 & 0,000462 & 0.001343 & 0,002939 & 0.004223 \\
\hline \multirow{2}{*}{ TAM } & $\beta$ & 0.000302 & 0,000700 & $0.002862 * * *$ & $0,004010^{*}$ & 0.002433 \\
\hline & e.p. & 0.000238 & 0,000682 & 0.000880 & 0,002308 & 0.004803 \\
\hline \multirow{2}{*}{ RISK } & $\beta$ & $-4.49 e-06$ & $-4,07 e-06$ & 0.000035 & 0,000020 & 0.000095 \\
\hline & e.p. & $7.45 e-06$ & 0,000023 & 0.000026 & 0,000029 & 0.000193 \\
\hline \multirow{2}{*}{ TPIB } & $\beta$ & 0.000136 & 0,000274 & 0.000233 & 0,000544 & -0.003244 \\
\hline & e.p. & 0.000089 & 0,000262 & 0.000853 & 0,001685 & 0.002765 \\
\hline
\end{tabular}




\section{TABle 4 (CONCLUSion)}

QUANTILE REGRESSION RESULTS POOLED

CROSS-SECTION FOR CHINESE COMPANIES

\begin{tabular}{lcccccc}
\hline & \multicolumn{5}{c}{ END } \\
\hline VARIABLES & & RQ 0.05 & RQ 0,25 & RQ 0.50 & RQ 0,75 & RQ 0.95 \\
\hline \multirow{2}{*}{ TINF } & $\beta$ & 0.000015 & $-0,000364^{*}$ & $-0.000487 * *$ & $-0,000246$ & 0.001680 \\
\cline { 2 - 7 } & e.p. & 0.000043 & 0,000189 & 0.000202 & 0,000426 & 0.001162 \\
\hline \multirow{2}{*}{ CRISIS } & $\beta$ & -0.000015 & $-0,000804$ & 0.001604 & 0,010130 & 0.008681 \\
\cline { 2 - 7 } & e.p. & 0.000278 & 0,001213 & 0.002893 & 0,006991 & 0.011317 \\
\hline \multirow{2}{*}{ Const. } & $\beta$ & $0.002374 * * *$ & $0,025016 * * *$ & $0.064858 * * *$ & $0,141883 * * *$ & $0.327355^{* * *}$ \\
\cline { 2 - 7 } & e.p. & 0.000135 & 0,000644 & 0.001396 & 0,003393 & 0.004586 \\
\hline Pseudo R2 & & 0.0006 & 0.0023 & 0,0043 & 0.0032 & 0,0023 \\
\hline Observations & & & 10181 & & \\
\hline
\end{tabular}

The variables studied were the long-term debt lagged the book value (END), the tangibility (TANG), profitability (LUCRAT), the opportunity for growth (OPORT), firm size (TAM); business risk (RISK), the growth rate of GDP (TPIB), inflation rate (TINF), and a dummy variable that captures the effects of the crisis (CRISIS). The definitions of variables of companies can be seen in section 2.3. This table shows the results for the estimation of regression parameters by the quantile regression method, robust standard error, using 2002-20II data. The coefficients equal test through quantile - (END) F= 59.43 (p > F = 0.0000). *** P < 0.0I; ** P < 0.05; * P < 0.I.

Source: Elaborated by the authors.

The size variable seems to be more decisive for the most indebted companies (quantile 0.50 and 0.75 ). The trade-off theory predicts that large companies will be more indebted, so large companies are more diverse and present a low risk of bankruptcy, as Frank and Goyal (2007b) present.

The effect of the crisis seems to have been milder for Chinese companies compared to companies from Brazil, Russia and India. However, the inflation rate showed an inverse relationship with debt for companies located in quantile 0.25 and 0.50 (contrary to the predictions of the trade-off theory).

Regarding the theories of capital structure, the results show evidence of tradeoff theory, for the overall business. Results were also observed by Ivashkovskaya and Solntseva (2008). 
Similar to the study of Jong et al. (2008), effects of factors specific to the companies, as tangibility, firm size, growth opportunity and risk, were observed. However, in this study, it was observed that in a country these determinants had different impacts for companies with different debt levels.

Analyzing the effects of macroeconomic factors on debt, it was observed that the inflation rate had influence on the debt, of companies in Russia, India and China. This result indicates that the economic condition (the expectation of increase/decrease in interest rates) enhance the effects of the determinants of capital structure. Observed fact analogously by Fan et al. (2004), stating that the economic policies as well as the legal environment and financial institutions play an important role in the way companies finance themselves.

\section{FINAL CONSIDERATIONS}

In recent decades, international studies (cross-country) on capital structure have aroused the interest of the scientific community. In this context, economic and institutional environment has been considered in the analysis of corporate financing decisions, since each country has its own characteristics that differentiate them, either emerging or developed.

Knowing what are the determinants of capital structure is not enough, because the financial literature indicates those that can be observed both in emerging countries as in developed countries. In addition, these factors can have their effects potentiated for economic and institutional factors of each country.

However, with the quantile regression, it was possible to analyze businesses under the various levels of debt. This technique allowed a richer reading of the sample while considering the heterogeneity of companies. In addition, with the subprime mortgage crisis, it was possible to observe the different effects of this event on companies from different countries. The effects of the crisis showed different intensities for companies in Brazil, Russia, India and China; not surprisingly, since they have different economic and institutional characteristics.

For Brazilian companies, the results indicated that the main determinants of capital structure do not appear to affect long-term debt (the results were not statistically significant). For Russian companies, evidence showed signs of both the pecking order theory as the trade-off theory, for quantile 0.50 and 0.75 ; and quantiles $0.05,0.025$ and 0.95 , respectively.

The analysis of Indian companies also suggests the observance of trade-off and pecking order theory. The most relevant variables for Indian companies were 
the "tangibility" (positive, trade-off), "growth opportunities" (negative, trade-off), "profitability" (negative, pecking order) and "size of the company" (positive, trade-off). It is noteworthy that, India was the only country analyzed that showed a reduction of long-term debt after the mortgage crisis.

For Chinese companies, evidences are favorable to trade-off. The "tangibility" and the "size of the company" (both positively related) exhibited greater influence in determining the debt.

This study sought to contribute to the literature on capital structure by analyzing emerging countries that represent a major share in the economic world; by analyzing countries with different characteristics (even with similar economic characteristics); by checking the determinants of capital structure in the context of world crisis; and, finally, by using the quantile analysis, method rarely used in the international studies on capital structure, in order to check the sensitivity of different levels of debt to firm and countries characteristics.

Regarding the limitations, there is a potential problem of omitted variables in the model analyzed that could possibly help to understand the financing strategies of the companies. Additionally, it is recommended to use a larger space for temporal analysis, running a quantile panel.

\section{ESTRUTURA DE CAPITAL DE BRASIL, RÚSSIA, ÍNDIA E CHINA MEDIANTE CRISE ECONÔMICA}

\section{RESUMO}

Objetivo: Verificar os efeitos da crise das hipotecas subprime sobre as empresas com níveis de endividamento diferentes.

Originalidade/lacuna/relevância/implicações: O trabalho contribui com a literatura financeira por analisar a estrutura de capital de empresas de países emergentes num contexto de crise, além de utilizar uma robusta ferramenta econométrica - a regressão quantílica.

Principais aspectos metodológicos: Neste trabalho, foi utilizada a regressão quantílica como ferramenta de análise. Esta técnica permitiu observar os impactos da crise não apenas no nível médio de endividamento das empresas, mas também em seus valores extremos. Assim sendo, este trabalho se caracteriza como descritivo, e as relações analisadas são de natureza quantitativa. Foram analisadas as empresas listadas nas Bolsas de valores do Brasil, Rússia, Índia, China. 
Síntese dos principais resultados: Os resultados sinalizaram estratégias de financiamento, segundo as teorias de Pecking Order e Trade-off de acordo com o nível de endividamento.

Principais considerações/conclusões: A pesquisa permitiu concluir que as empresas apresentam estratégias de financiamento diferentes, num mesmo país. Assim, o comportamento financeiro das empresas seria influenciado pelas condições econômicas do país, bem como pelo nível de endividamento existente em cada empresa.

\section{PALAVRAS-CHAVE}

Pecking order. Trade-off. Estrutura de capital. Países emergentes. Crise econômica.

\section{ESTRUCTURA DE CAPITAL DE BRASIL, RUSIA, INDIA Y CHINA POR LA CRISIS ECONÓMICA}

\section{RESUMEN}

Objetivo: Comprobar los efectos de la crisis de hipotecas de alto riesgo en empresas con diferentes niveles de deuda.

Originalidad/laguna/relevancia/implicaciones: El estudio contribuye a la literatura mediante el examen de la estructura de capital financiero de las compañías de mercados emergentes en un contexto de crisis, además de utilizar una herramienta robusta econométricos - la regresión cuantil.

Principales aspectos metodológicos: En este trabajo se utilizó como herramienta de análisis de regresión cuantil, esta técnica permitió observar los impactos de la crisis no sólo en el nivel medio de endeudamiento de las empresas, sino también en sus valores extremos. Por lo tanto, este trabajo se caracteriza por ser descriptiva y se analizaron las relaciones son cuantitativos. las sociedades cotizadas se analizaron en las bolsas de Brasil de los valores, Rusia, India, China.

Síntesis de los principales resultados: Los resultados indican estrategias de financiación, de acuerdo con las teorías de la Jerarquía y Comercio de despegue de acuerdo con el nivel de la deuda.

Principales consideraciones/conclusiones: El estudio concluyó que las empresas tienen diferentes estrategias de financiación, en el mismo país. Por lo tanto, los resultados financieros de las empresas se vería influenciada por las condiciones económicas en el país, así como el nivel de deuda existente en cada empresa. 


\section{PALABRAS CLAVE}

Pecking order. Trade-off. Estructura de capital. Los países emergentes. Crisis económica.

\section{REFERENCES}

Alexander, M., Harding, M., \& Lamarche, C. (20II). Quantile regression for time-series-cross-section data. International Journal of Statistics and Management System, 6(I-2), 47-72.

Almeida, P. R. (20I0). O Bric e a substituição de hegemonias: um exercício analítico (perspectiva histórico-diplomática sobre a emergência de um novo cenário global). In R. Baumann (Org.). O Brasil e os demais BRICs - Comércio e Política. Brasília, DF: CEPAL Escritório no Brasil/IPEA.

Amutha, D. (20I4). Monetary sector reforms in India. Social Science Research Network. Retrieved 20I6, from http://ssrn.com/abstract=2505693. DOI: http://dx.doi.org/10.2139/ssrn.2505693.

Antoniou, A., Guney, Y., \& Paudyal, K. (2008). The determinants of capital structure: capital market oriented versus bank oriented institutions. Social Science Research Network. Retrieved 20I5, from http://ssrn.com/abstract=IOI94I8.

Arellano, M., \& Bond, S. (I99I). Some test of specification for panel data: Monte Carlo evidence and an application to employment. The Review of Economic Studies, 58(2), 277-297.

Barros, L. A. B. C., Castro, F. H. F. J., Silveira, A. D. M., \& Bergmann, D. R. (2010). A questão da endogeneidade nas pesquisas empíricas em finanças corporativas: principais problemas e formas de mitigação. Social Science Research Network. Retrieved 20I5, from http://ssrn.com/abstract=1593187.

Bastos, D. D., Nakamura, W. T., \& Basso, L. F. C. (2009). Determinantes da estrutura de capital das companhias abertas na América Latina: um estudo empírico considerando fatores macroeconômicos e institucionais. Revista de Administração Mackenzie, 10(6), 47-77.

Bekaert, G., \& Harvey, C. R. (2002). Research in emerging markets finance: looking to the future. Social Science Research Network. Retrieved 20I6, from http://ssrn.com/abstract=795364.

Booth, L., Aivazian, V., Demirguc-Kunt, A., \& Maksimovic, V. (200I). Capital structures in developing countries. The Journal of Finance, 56(I), 87-130.

Brounen, D., Jong, A., \& Koedijk, K. (2005). Capital structure policies in europe: survey evidence. Social Science Research Network, n. ERS-2005-005-F\&A. Retrieved 20I6, from http://ssrn.com/abstract=7979I9.

Cameron, A. C., \& Trivedi, P. K. (2005). Microeconometrics - Methods and Applications. Cambridge: Cambridge ISE.

Cameron, A. C., \& Trivedi, P. K. (2010). Microecinometrics Using Stata. College Station: Stata Press. Campello, M., Graham, J. R., \& Harvey, C. R. (2009). The real effects of financial constraints: evidence from a financial crisis. Social Science Research Network. Retrieved 20I6, from http://ssrn.com/abstract=I318355.

Cervo, A. L., Bervian, P. A., \& Dasilva, R. (2007). Metodologia Científica. São Paulo: Pearson Prentice Hall. 
Chernozhukov, V., Hansen, C., \& Jansson, M. (2006). Finite sample inference for quantile regression models. Social Science Research Network. Retrieved 20I6, from http://ssrn.com/abstract $=880467$.

Desai, M. A., Foley, C. F., \& Forbes, K. J. (2004). Financial constraints and growth multinational and local firm responses to currency crises. Working Paper. Retrieved 2015, from http://www.nber. org/papers/wio545.

Fan, J. P. H., Titman, S., \& Twite, G. (20I2). An international comparison of capital structure and debt maturity choices. Journal of Financial and Quantitative Analysis, 47(I), 23-56.

Fattouh, B., Scaramozzino, P, \& Harris, L. (2003). Capital structure in south Korea: a quantile regression approach. Social Science Research Network. [Paper Series n. 40]. Retrieved 2016, from http://ssrn.com/abstract=47494I. DOI: http://dx.doi.org/IO.2I39/ssrn.47494I.

Fattouh, B., Scaramozzino, P., Harris, L. (2008). Non-linearity in the determinants of capital structure: evidence from UK firms. Empirical Economics, 34, 4I7-438. DOI: http://dx.doi.org/10.2139/ ssrn.789304.

Favato, V., \& Rogers, P. (2008). Estrutura de capital na América Latina e nos Estados Unidos: uma análise de seus determinantes e efeito dos sistemas de financiamento. Gestão \& Regionalidade, 24(7I-Edição Especial.), 3I-43.

Frank, M. Z., \& Goyal, V. K. (2007). Trade-off and pecking order theories of debt. Social Science Research Network. Retrieved 20I6, from http://ssrn.com/abstract=670543.

Frank, M. Z., \& Goyal, V. K. (2007a). Profits and capital structure. Social Science Research Network. Retrieved January 23, 20I4, from http://ssrn.com/abstract=IIO4886.

Frank, M. Z., \& Goyal, V. K. (2007b). Capital structure decisions: which factors are reliably important? Financial Management, 38(I), I-37.

Hallock, K. F., Madalozzo, R., \& Reck, C. G. (2008). CEO pay-for-performance heterogeneity using quantile regression. Working Paper. Cornell University.

Hovakimian, A., \& Li, G. (2009). Do firms have unique target debt ratios to which they adjust? Social Science Research Network. Retrieved 20I5, from http://ssrn.com/abstract=II38316.

International Monetary Fund (IMF). (20I0). World economic outlook: rebalancing growth. Washington, DC: IMF.

International Monetary Fund (IMF). (20I2). World economic outlook: Growth Resuming, Dangers Remain. Washington, DC: IMF.

Ivashkovskaya, I., \& Solntseva, M. (2008). Do Russian, Brazilian and Chinese firms follow pecking order or trade-off logic of financing? Eleventh Annual Conference of the GBATA, Prague.

Jensen, M. C., \& Meckling, W. H. (I976). Theory of the firm: managerial behavior, agency costs and ownership structure. Journal of Financial Economics, 3(4), 305-360.

Jong, A., Kabir, R., \& Nguyen, T. T. (2008). Capital structure around the world: The roles of firmand country-specific determinants. Journal of Banking \& Finance, 32(9), 1954-1969.

Koksal, B., \& Orman, C. (20I4). Determinants of capital structure: Evidence from a Major Developing Economy. Social Science Research Network. Retrieved May I8, 20I4, from http://ssrn.com/ abstract=2212648.

Lemmon, M. L., Roberts, M. R., \& Zender, J. F. (2008). Back to the beginning: persistence and the cross-section of corporate capital structure. The Journal of Finance, 63(4), I575-1608. 
Lima, F. G., Assaf, A., Neto, Perera, L. C. J., \& Silva, A. C., Filho (20II). The impacts in the capital structure of Brazilian companies during periods of crisis. Journal of International Finance and Economics, 11(2), I54-160.

Mojtahedzadeh, V. (20II). Tests of capital structure "static trade-off" and "pecking order" theories in Iran. Social Science Research Network. Retrieved March 3, 20I4, from http://ssrn.com/abstract=I9I5955.

Myers, S. C. (I977). Determinants of corporate borrowing. Journal of Financial Economics, 5(2), I47-I75.

Myers, S. C. (2003). Financing of corporations, In G. Constantinides, M. Harris, \& R. Stulz. Handbook of the Economics of Finance: Corporate Finance. North Holland: Elsevier.

Oliveira, G. R., Tabak, B. M., Resende, J. G. L., \& Cajueiro, D. O. (20I2). Determinantes da estrutura de capital das empresas brasileiras: uma abordagem em regressão quantílica. [Working Paper 272], Trabalhos para Discussão, Banco Central do Brasil, Brasília, DF.

Öztekin, O. (20II). Capital structure decisions around the world: which factors are reliably important? Journal of Financial and Quantitative Analysis (JFQA). Retrieved 20I5, from http://ssrn.com/ abstract=I46447I. DOI: http://dx.doi.org/I0.2139/ssrn.I46447I.

Rajan, R., \& Zingales, L. (I995). What do we know about capital structure? Some evidence from international data. The Journal of Finance, 50(5), I42I-I460.

Reddy, K. S. (2015). Macroeconomic change, and cross-border mergers and acquisitions: the indian experience, I99I-20I0. Social Science Research Network. Retrieved 20I6, from http://ssrn. com/abstract $=2680099$.

Shyam-Sunder, L., \& Myers, S. C. (I999). Testing static tradeoff against pecking order models of capital structure. Journal of Financial Economics, 5I, 219-244.

Strebulaev, I. A. (2007). Do tests of capital structure theory mean what they say? The Journal of Financial, 62(4), I747-I787.

Wellalage, N. H., \& Locke, S. (20I2). Capital structure and its determinants in New Zealand firms. Journal of Business Economics and Management, New Zealand. Retrieved June 13, 2013, from http:// ssrn.com/abstract=2115268. 